\title{
A BANALIDADE DO MAL E O JULGAMENTO DE EICHMANN
}

Fabiano Miranda do N. Tizzo ${ }^{1}$

\section{THE BANALITY OF EVIL AND EICHMANN'S JUDGEMENT}

RESUMO: O artigo tem por objetivo analisar a visão de Hannah Arendt (1906 -1975) sobre o julgamento do exnazista Otto Adolf Eichmann (1906 -1962) e a ideia de banalidade do mal pensada pela autora ao longo do julgamento. Para Arendt, o totalitarismo nazista criou um modelo novo de criminoso, pois o extermínio sistemático e organizado de milhões de seres humanos não é visto somente como monstruosidade por parte de um grupo, mas um ato cometido por pessoas que cumpriam meras obrigações burocráticas, assim como Eichmann. Portanto, a análise concentrar-se-á no cumprimento de ordens associado à irreflexão, responsabilidade legal, inversão de valores morais provocadas pelo Estado nazista, nos massacres administrativos e o perfil do réu

Palavras-chave: Eichmann. Arendt. Julgamento. Moral. Responsabilidade.
ABSTRACT: This article aims to analyze the vision of Hannah Arendt (1906-1975) on the trial of former Nazi Otto Adolf Eichmann (1906-1962) and the banality of evil idea conceived by the author during the trial. For Arendt, the Nazi totalitarianism created a new model of criminal, because the systematic and organized extermination of millions of human beings is not only seen as a monstrosity by a group, but an act committed by people who met mere bureaucratic obligations, as well as Eichmann. Therefore, the analysis will focus on fulfilling orders associated with thoughtlessness, legal liability, and reversal of moral values caused by the Nazi state, administrative massacres and the defendant's profile.

Keywords: Eichmann. Arendt. Judgment. Moral. Responsibility.

\footnotetext{
${ }^{1}$ Professor da Universidade de Santo Amaro e Faculdade Tijucussu. Mestre em História Social pela PUC SP (2015). Especialização em Política e Relações Internacionais pela Escola de Sociologia e Política de São Paulo-FESPSP (2013); Especialização em História pela PUC- de Sociologia, História e Ciência Política. SP (2011) e, em Arqueologia na Universidade de Santo Amaro-UNISA (2012).
} 


\section{INTRODUÇÃO}

Em 1961, logo após a prisão do ex-nazista Eichmann, a renomada intelectual Hannah Arendt se ofereceu como enviada especial da Revista The New Yorker para fazer a cobertura do julgamento e depois publicou um texto composto de cinco capítulos (ARENDT, 2013, p. 05). Posteriormente, os capítulos publicados deram origem ao livro "Eichmann em Jerusalém - um relato sobre a banalidade do mal"2 que, publicado em maio de 1963, tornou-se uma edição ampliada da cobertura do processo. A obra citada é a principal fonte deste artigo por ser um documento histórico relevante, uma vez que Arendt compareceu ao julgamento e pautou-se em diversos documentos sobre o caso para produzi-lo, pois de acordo com Bittar "Arendt possui um olhar clínico para análise das trevas que dominaram a política" em seu tempo ao perceber que o totalitarismo transformou o crime em algo correto, desejável e legal. (BITTAR, 2011, p. 277).

Com base nos escritos de Arendt e por meio da bibliografia especializada, escrita por estudiosos da autora, faremos uma análise sobre sua visão diante do caso Eichmann e a contextualização sobre a banalidade do mal, conceito cunhado pela autora ao assistir o julgamento. Nosso objetivo com o presente artigo é compreender sociologicamente a visão que Hannah Arendt lançou sobre Eichmann e seu julgamento, com base nos argumentos por ela levantados e respaldados na pesquisa, buscaremos explicar como foi possível a um homem intelectualmente tão limitado encontrar condições favoráveis no coro de serviços de uma organização estatal criminosa que conduziu milhões de pessoas ao extermínio em seu tempo e o possível risco de uma suposta repetição histórica.

Sendo assim, faz-se necessário explicitar como o presente artigo está estruturado. Foi organizado em três partes de maneira que a leitura e a compreensão da temática acerca do pensamento de Arendt fluam com facilidade, a saber:

Na primeira parte, será demonstrado as especificidades quanto ao perfil do réu, a maneira como se posicionava e argumentava ao longo do julgamento e a visão peculiar de

\footnotetext{
${ }^{2}$ Segundo Adler, em 1964, "Eichmann em Jerusalém é agora lido e comentado no mundo inteiro, fala-se dele na televisão e não apenas nos meios universitários" (ADLER, 2007, p. 483). Este foi um livro que desatou "uma das mais amplas e complicadas controvérsias do século XX" (YOUNG BRUEHL, 2006, p. 21).
} 
um ex-nazista sobre o contexto e as vítimas, bem como a forma de Estado no qual o réu vivia. É análise inicial sobre o nosso objeto de estudo.

$\mathrm{Na}$ segunda, refere-se ao panorama e contextualização do julgamento sob a perspectiva do conceito de banalidade do mal cunhado por Hannah Arendt e aos aspectos do fenômeno totalitário nazista alinhado ao contexto do tribunal e às consequências da ausência do pensar, refere-se à uma análise e discussão mais profunda de nosso objeto.

Na última parte, refere-se à conclusão, esta última direcionada no plano macro e microssociológico, pois destacamos os efeitos e o resultado com base na inversão de valores promovida não apenas na sociedade alemã ao longo do nazismo, mas de outros regimes de governo que impõem a ausência do pensar e ignoram os valores humanitários em favor de uma ideologia, de um partido político, ou de um projeto de nação que prometa o suposto "bem maior" em sacrifício de minorias e com a submissão da esfera jurídica legal, como fez o totalitarismo nazista.

\section{O PERFIL DO RÉU}

Quanto ao réu Otto Adolf Eichmann, sua trajetória começa quando se filia ao Partido Nazista, em abril de 1932. Após a derrota e a invasão das tropas aliadas à Alemanha, alguns nazistas foram capturados e outros se entregaram. Muitos deles foram julgados e condenados à morte pelo Tribunal de Nuremberg, onde o nome de Eichmann foi citado ao longo dos julgamentos. Alguns deles não chegaram a ser julgados, por terem cometido suicídio, inclusive o Führer, Adolf Hitler, que se suicidou em 30 de abril de 1945 ao perceber que a guerra estava perdida. Eichmann, por exemplo, foi capturado por tropas americanas, porém, conseguiu fugir em 1946, escondendo-se na Argentina até 11 de maio de 1960, quando foi preso e posteriormente levado a julgamento.

Dentre as acusações que recaíam sobre ele estava em questão sua participação direta em uma estrutura ampla de extermínio de seres humanos - particularmente o povo judeu - visto também como crime contra a humanidade. Com base em uma "lei israelense 
criada em $1950^{\prime \prime 3}$ para punir criminosos de guerra ligados ao nazismo, Eichmann passou a responder por quinze acusações, conforme segue:

(1) Provocar o assassinato de milhões de judeus; (2) Levar milhões de judeus a condições que poderiam levar à destruição física; (3) Por causar sérios danos físicos e mentais aos judeus; (4) Determinar que fossem proibidos os nascimentos e interrompidas as gestações de mulheres judias no campo de concentração Theresienstadt; (5) "Resumia os itens 1 e 2", como: propiciar condições que visavam a morte de milhões de judeus por meio da fome, deportação, trabalhos forçados, condições sub-humanas, destruição física e psicológica, cárcere...; (6) Por perseguir judeus com base em motivos raciais, religiosos e políticos; (7) Pilhagem de propriedade: confiscar bens de judeus através de medidas que envolviam a extorsão, o roubo e a violência; (8) Era responsável por crimes de guerra; (9) Pela expulsão de centenas de milhares de poloneses de suas casas; (10) Responsável pela deportação de 1400 eslovenos da lugoslávia; (11) Era responsável pela deportação de milhares e milhares de ciganos para o campo de concentração Auschwitz; (12) Era responsável pela deportação e morte de 93 crianças da aldeia de Lidice, uma aldeia tcheca. Os três últimos itens o acusavam de pertencer a três organizações consideradas criminosas pelo Tribunal de Nuremberg: SD, Gestapo e SS. (ARENDT, 2013, p. 266-269).

As doze primeiras acusações já eram suficientes para que se aplicasse a pena de morte. De acordo com Arendt, "Eichmann se declarou inocente de todas as acusações" e não se sentia responsável pelo fato de ter cumprido ordens de seu governo (ARENDT, 2013, p. 32). Mesmo diante da enormidade dos crimes cometidos, a corte israelense teve inúmeras dificuldades para sentenciá-lo, o que levou Arendt a questionar o próprio significado do julgamento e a tipificação do crime pelo qual ele fora indiciado e criticar a não existência de leis que se referissem a crimes contra a humanidade ou genocídio, afirmando que o "sistema legal dominante e os conceitos jurídicos em uso eram inadequados e insuficientes para avaliar o que ela denominou por massacres administrativos" (ARENDT, 2013, p. 317). Era um réu que cometera crimes diferenciados em sua época que nunca haviam sido julgados pelo Tribunal de Jerusalém que o julgou, pois o regime "totalitário nazista descobriu, sem o saber, que existem crimes que os homens não podiam punir nem perdoar" (ARENDT, 2009, p. 510).

Eichmann cumpria ordens superiores sem jamais tê-las questionado ou sequer refletir sobre o que fazia, sendo que essa ausência do pensar e o cumprimento de ordens

\footnotetext{
${ }^{3}$ A Corte Distrital de Jerusalém fundamentou o julgamento de Eichmann com base nesta "Lei de Punição dos Nazistas e Colaboradores de Nazistas". Ela possibilitava a aplicação da pena de morte para aqueles que ao longo do regime nazista (1933-1945) cometeram crimes contra o povo judeu. ARENDT, H. Eichmann em Jerusalém, 2013, p. 32-268.
} 
foram vitais ao sucesso do nazismo. Para Arendt, era essencial que Eichmann "fosse levado a sério" (ARENDT, 2013, p. 67). Era fundamental compreender o tipo de mentalidade de homens como ele, isso poderia contribuir para evitar que mais indivíduos com esse perfil encontrassem espaço em outras organizações criminosas como foi o nazismo, que transformou seres humanos em algo supérfluo, conforme será explicitado adiante. Além disso, é importante ressaltar sobre o cuidado que se deve ter para que não haja "um Eichmann dentro de cada um de nós". (ARENDT, 2013, p. 309).

\section{O JULGAMENTO, A BANALIDADE DO MAL E O TOTALITARISMO}

Arendt explica o caso Eichmann como um novo fenômeno no século XX. Para a autora, não se trata simplesmente de considerar que Eichmann era dantesco ou monstruoso, mas que, a exemplo de muitos indivíduos, banalizava o mal, agindo de forma indiferente mesmo ao praticar crimes hediondos. Eichmann, embora partícipe de crimes abomináveis, é visto por ela como um homem simples, banal e medíocre. Quando ela esteve pessoalmente no julgamento, ao observar o réu diretamente, sentiu-se incomodada ao perceber que ele foi mantido em uma cabine de vidro e que esta tinha como objetivo "protegê-lo dos judeus", afinal, ele era acusado pela morte de milhões deles.

Eichmann era o tipo de burocrata que não sujava as mãos com o sangue de suas vítimas, pois era um homem de gabinete que cometia "massacres administrativos" (ARENDT, 2013, p. 317). Assinava documentos e batia carimbos em sua escrivaninha e, ao fazê-lo, milhões de seres humanos eram transportados sob seu comando. Foi considerado responsável pela operação de toda a logística de transportes que conduziu inúmeras pessoas aos campos de concentração e evacuação forçada em lugares que foram ocupados e administrados pelos nazistas, antes e após a tomada do poder em 1933.

Embora fosse somente um cumpridor de ordens nessa estrutura ampla, isso não o isentava dos atos cometidos, nem quer dizer que ele fosse um tolo. "Ele não era burro", afirmou a autora (ARENDT, 2013, p. 311). Segundo Ferraz, Eichmann "sabia bem o que fazia, o que o caracterizava era um vazio de pensamento que não quer dizer tolo, mas que o tornou o grande criminoso que acabou sendo" (FERRAZ, 1983, p. 09). "Foi pura irreflexão 
- algo de maneira nenhuma idêntico à burrice - que o predispôs a se tornar um dos grandes criminosos desta época" (ARENDT, 2013, p. 311).

Eichmann obedecia às ordens com muita lealdade e presteza, no desempenho de suas atribuições. Ao exercê-las não era capaz de refletir sobre a amplitude das ordens recebidas, sendo este um dos aspectos mais impactantes deste julgamento. Era somente um funcionário de seu governo e não da pior espécie do totalitarismo nazista como a maioria, ou seja, não era do tipo que sentia prazer em ver jorrar sangue de vítimas indefesas. Segundo Ferraz, "Eichmann nunca tocou em uma arma” (FERRAZ, 1983, p. 10). Era o tipo de burocrata que acreditava no valor das ordens que recebia e se orgulhava em realizar o seu trabalho bem feito.

Ainda que ficasse comprovado que o réu jamais usara uma arma de fogo contra qualquer judeu, além da incansável alegação de inocência com base no cumprimento de ordens, Arendt observa o quanto eram contraditórias algumas de suas falas ao longo das sessões de seu julgamento:

\begin{abstract}
Com o assassinato dos judeus não tive nada a ver. Nunca matei um judeu, nem um não judeu - nunca matei nenhum ser humano. Nunca dei uma ordem para matar fosse um judeu fosse um não judeu; simplesmente não fiz isso"; ou como confirmaria depois [...] não deixou nenhuma dúvida de que teria matado o próprio pai se houvesse recebido uma ordem nesse sentido. [...] A acusação deixava implícito que ele não só agira conscientemente, coisa que ele não negava, como também agira por motivos baixos e plenamente consciente da natureza criminosa de seus feitos. (ARENDT, 2013, p. 33 e 37).
\end{abstract}

Ao expor o que pensava sobre Eichmann, Arendt desvela um fenômeno que passa a ser debatido com intensidade: aquele que perpetua o mal não precisa ser forçosamente um indivíduo sádico, genocida, monstruoso ou perverso - não é apenas isso que distingue a barbárie ou a prática do mal. Para ela, o ato de se exterminar pessoas "pode se tornar somente um assunto administrativo nas estruturas da burocracia que domina o fazer moderno" (GRESPAN, 2013, p. 155). Tratava-se do simples cumprimento de ordens por um homem medíocre que as executava com zelo meramente profissional; haja vista que ele "sequer nutria ódio pelos judeus ou era um antissemita fanático pelos ideais de seu partido" (ARENDT, 2013, p. 37 e 269). Inclusive, Eichmann "comentou que foi ajudado por uma família judia influente" quando esteve desempregado, antes de se filiar ao partido 
nazista (ARENDT, 2013, p. 41). Ou seja, era de uma absoluta indiferença pelas vítimas e obediência cega às leis.

É exatamente por não ter motivos especiais que "um mal dessa natureza pode se espraiar indefinidamente como um fungo sobre a superfície e devastar o mundo" (CORREIA, 2007, p. 52). É esse fenômeno que Arendt denomina a banalidade do mal, como define Lafer:

O exercício da gratuidade do mal ativo, que leva a atos monstruosos cometidos por pessoas ordinárias, é, avalia Hannah Arendt, fruto de thoughlessness, uma incapacidade de pensar dos que os perpetram. Esta incapacidade corre o risco de generalizar-se e é extrema (por isso é perigosa), mas não profunda (por isso é banal). Tem, no entanto, o potencial de irradiar-se como um fungo rasteiro e nefasto, que pode espalhar-se pelo mundo, destruindo-o [...]. (LAFER, 2013, p. 33).

Para a autora, Eichmann era um homem comum dentro da lógica do nazismo, "um novo indivíduo "normal" dentro da nova "norma social" (GRESPAN, 2013, p. 168). Era uma lógica moral nova e também inimaginável antes; seus crimes não somente eram bem planejados e terrivelmente organizados, mas desconhecidos e seguiam uma lógica de conduta social própria e diferenciada.

O regime de governo nazista inverteu a ordem e os valores morais em sua sociedade e ofereceu como matéria prima homens como Eichmann: "O mal se converteu em norma, estava generalizado e banalizado" e sua figura pequena era a banalidade do mal em pessoa em pleno século XX (GRESPAN, 2013, p. 169). A expressão banalidade do mal não significa que a prática do mal pelos nazistas era vista por Arendt como banal, mas, sim, que era vista pelos nazistas como banal. O conceito de banalidade do mal de Arendt não afirma sobre uma suposta essência do mal, "não é uma questão ontológica uma vez que não se apreende uma essência do mal, mas sim uma questão no plano da ética e da política" (SOUKI, 2006, p. 99 e 100). A banalidade do mal não está necessariamente em um plano metafísico, ela é parte do meio político, histórico, é uma condição humana. O "problema do mal sai, verdadeiramente, dos âmbitos teológico, sociológico, psicológico e passa a ser focado na sua dimensão política" (SOUKI, 2006, p. 100). Torna-se um fenômeno humano "fruto do não exercício da liberdade" que se aproxima do homem na medida em 
que ocorre um vazio no pensamento associado a algum estado de crise moral como foi o totalitarismo (SOUKI, 2006, p. 67).

Para Arendt, não era Eichmann a engrenagem ou motor do sistema, e sim somente “parte de um aparato burocrático gigante que utilizava os recursos do governo" (ARENDT, 2013, p. 312). Visava "condenar judeus ao extermínio não pelo que fizeram enquanto indivíduos, mas porque eram parte de um grupo em que nasceram e foram jogados pela legislação nazista" (LAFER, 2013, p. 27 e 31). Os judeus foram condenados à morte somente pelo que eram, pois os nazistas "determinaram quem deveria e quem não deveria habitar o mundo" (ARENDT, 2013, p. 302).

Chama-nos atenção a capacidade de Arendt de expor e indagar sobre as peculiaridades do réu. Alguns apontamentos feitos pela autora são expressados por meio de adjetivos que, além de evidenciar o perfil de Eichmann, expõem sua indignação ante o ocorrido. Ela se mostrou atônita dada a pequenez do sujeito e a imensidão destrutiva que um homem de inteligência tão limitada foi capaz de alcançar. Portanto, ela atribui a Eichmann adjetivos tais como: normal, comum, banal, superficial, constrangedor, fracassado, vaidoso, mentiroso, medíocre, incapaz de pensar, mediano, frustrado, palhaço.

Todos esses adjetivos denotam que a ausência do pensar é um dos principais problemas de Eichmann, pois durante o julgamento ele foi incapaz de construir uma frase bem sustentada em sua defesa. Embora a autora não afirme, fica-nos a impressão de que o réu era somente um homem inepto, mas foi capaz de causar um dos maiores males que já se fez à humanidade. Um mal que envolveu o extermínio de milhões de seres humanos foi cometido por um homem limitado intelectualmente e cegamente leal ao cumprimento das ordens que recebia, movido pela obsessão de ser um burocrata exemplar, como cita Arendt:

quanto mais se ouvia Eichmann, mais óbvio ficava que sua incapacidade de falar estava intimamente relacionada com sua incapacidade de pensar, ou seja, de pensar pelo ponto de vista dos outros. Não era possível nenhuma comunicação com ele, não porque mentia, mas porque se cercava do mais confiável de todos os guarda-costas contra as palavras e a presença de outros, e portanto contra a realidade enquanto tal (ARENDT, 2013, p. 62).

Segundo Ferraz, ele "não era o tipo perverso de criminoso, cínico ou atrevido, não era um ambicioso capaz de matar ou de fechar os olhos para progredir, mas sim alguém 
que jamais teria imaginado o que estava fazendo" (FERRAZ, 1983, p. 09). É como se Eichmann não refletisse e não percebesse ou não fosse sensível o suficiente para interpretar a amplitude maléfica de seus feitos. Mesmo assim, não era visto pela autora como um homem inocente e que apresentasse desvios de comportamento ou indícios de insanidade mental; ao contrário, Eichmann "foi avaliado por pelo menos seis psiquiatras que atestaram sua dita "normalidade" (ARENDT, 2013, p. 37). Ele não era um agente ou um potente cérebro voltado à prática do mal, mas, sim, parte de uma base estrutural para que a prática do mal se concretizasse e se tornasse banal - o que gerou espanto para a autora que o concebeu como uma figura "constrangedora e superficial - afastando-o de tal modo da imagem dos grandes vilões, era difícil para ela vê-lo como um monstro capaz de cometer males impensáveis" (CORREIA, 2007, p. 49). Segundo Arendt, "apesar de todos os esforços da promotoria, todo mundo percebeu que esse homem não era um "monstro", mas era difícil não desconfiar que ele fosse um palhaço" (ARENDT, 2013, p. 67).

Outro aspecto a considerar são as falas de Eichmann analisadas por Arendt ao longo do julgamento; levam-nos a vê-lo como uma das figuras mais toscas no panorama dos homens nazistas. A autora o descrevia não apenas como "uma figura comum e banal" (ARENDT, 2013, p. 311). Mas também um homem que pensava por clichês:

[...] Eichmann, apesar de sua má memória, repetia palavra por palavra as mesmas frases feitas e clichês semi-inventados (quando conseguia fazer uma frase própria, ele a repetia até transformá-la em clichê) toda vez que se referia a um incidente ou acontecimento que achava importante. [...] ele dizia sempre a mesma coisa, expressa com as mesmas palavras. (ARENDT, 2013, p. 62).

Quando Ihe perguntaram se ele se arrependia do que fez, Eichmann respondeu "Arrependimento é para criancinhas" (ARENDT, 2013, p. 36). Em outra ocasião quando foi pressionado pela corte, reclamou dizendo "que tinha sido frito até o bife queimar" (ARENDT, 2013, p. 245). Em outra situação, respondeu e sugeriu à corte o seguinte: “Posso ser enforcado em público como exemplo para todos antissemitas da Terra" (ARENDT, 2013, p. 66).

Os clichês eram comuns entre os nazistas e o hábito de Eichmann de responder por clichês trouxe inúmeras dificuldades ao longo do julgamento, principalmente no que diz respeito à busca pela verdade, pois até mesmo para isso ele tinha um clichê: "Um dos 
poucos dons com que o destino me abençoou é a capacidade para a verdade, na medida em que ela depende de mim", disse ele (ARENDT, 2013, p. 67). Dizer a verdade não era uma qualidade e de Eichmann e "esse horrível dom de se consolar com clichês não o abandonou nem na hora de sua morte" (ARENDT, 2013, p. 68). Era uma capacidade de expressão oriunda de seu tempo e muito usual pelos nazistas.

Eichmann "era mais um homem comum que aprendera a recitar mecanicamente os chavões ideológicos de seu partido" (DUARTE, 2000, p. 342). É como se a sua linguagem codificada o protegesse contra a realidade da corte que o julgava, mesmo depois de tantos anos fora do Partido Nazista, ele ainda não havia conseguido se desprender dos vícios de linguagem sua época. Isto quer dizer que era incapaz de refletir para além da esfera técnica de seu partido totalitário, "alheio a qualquer demanda de pensamento e juízo" (DUARTE, 2000, p. 343). Era um sujeito afastado da realidade comum daquilo que Arendt chama de espaço público, que se dá meio a relação com outros indivíduos que pensam diferente e dialogam entre si e assim se constrói o novo, pois as ideias estão sempre em debate e mais ideias podem ser construídas em conjunto.

O totalitarismo baniu a possibilidade do homem comum pertencer à esfera pública e impôs uma realidade superficial, portanto, suprimiu a pluralidade de ideias e a interação entre os indivíduos para que não houvesse o novo e sim somente a ideologia oficial. É esse também um dos principais problemas visto no julgamento, pois o distanciamento da realidade da esfera pública gerou uma grande irreflexão entre os homens do nazismo e com Eichmann, estes que tornaram-se superficiais no pensar, agir e até falar, daí os clichês com frases prontas e fáceis e a disposição em obedecer sempre, obediência passou a ser visto por eles como disciplina. Quando Eichmann se "defrontava com situações em que não havia nenhuma frase pronta ficava totalmente desorientado" (ARENDT, 2003, p. 145). Essa irreflexão propiciada pela ausência da realidade, levou-os a "crueldade e aceitação do extermínio como sendo uma solução perfeitamente normal" (ARENDT, 2009, p. 496). Tornaram-se sujeitos obedientes e de fácil manipulação em favor da ideologia e abnegaram do poder de questionamento, pois a convicção de "se fazer o certo e evitar o errado tende a ser construída moralmente e no relacionamento do homem consigo mesmo, o que seria suficiente" (ARENDT, 2004, p. 131). Mas após o totalitarismo houve a 
impossibilidade de participação e livre ação ou interação espontânea dos indivíduos, pois a imposição da proposta totalitária tinha como conduta moral "a introdução da criminalidade no domínio público" (ARENDT, 2004, p. 86). Ou melhor, inverteu os valores morais, pois aquilo que era negativo e criminoso tornou-se positivo e assim suas vítimas tornaram-se algo supérfluo em uma estrutura legal, conforme será explicitado em nossas conclusões a seguir.

\section{CONCLUSÃO}

Percebe-se que a autora levou em consideração o tipo de raciocínio que Eichmann possuía, não apenas o que fez, mas o que pensava a respeito do que fazia enquanto executava as ordens de seu regime. Seus apontamentos nos levam a pensar que o réu "era incapaz de pensar com a ausência de um regulamento" (CORREIA, 2007, p. 50). "Mais importante do que saber como seguir uma regra é saber por que é que se deve segui-la" (DUARTE, 2000, p. 342). Esse tipo de análise não parece ter sido pensado por Eichmann. De forma que obedeceu - sem se responsabilizar pessoalmente pelas consequências morais de seus atos - e sem cogitar se eles poderiam ocasionar algo maléfico, destrutivo, cruel e danoso. Ou seja, seguiu todo o regulamento, tratou o extermínio como uma rotina de tarefas, um assunto meramente administrativo e burocrático, por obediência às leis, sob um ponto de vista profissional, sem ódio, fanatismo ou senso de horror pelo que praticava. Segundo Arendt, Eichmann não era capaz de estabelecer o precioso diálogo de pensamento "entre mim e mim mesmo que, desde Sócrates e Platão, chamamos de pensar" (ARENDT, 2004, p. 107). Para Souki, ele era o homem ideal e perfeito para levar adiante a empreitada que era encarregado, como cita a autora:

na sua função de encarregado do transporte, ele era normal e medíocre e, no entanto perfeitamente adaptado a seu trabalho que consistia em "fazer as rodas deslizarem suavemente" [...] Sua função era tornar a "solução final", normal. Com sua vaidade e exibicionismo e seus clichês pretensiosos, ele era, ao mesmo tempo, ridículo e ordinário. Eichmann representava o melhor exemplo de um assassino de massa que era, ao mesmo tempo, um perfeito homem de família. Chamar alguém de monstro não o torna mais culpado, da mesma forma que chamá-lo de besta ou demônio. [...] Afigurava-se como algo totalmente negativo: não se tratava de estupidez, mas de uma curiosa e bastante autêntica incapacidade de pensar (SOUKI, 2006, p. 88). 
É a esse fenômeno que Arendt denomina como banalidade do mal, expressão que se aplica a indivíduos como Eichmann que, convencidos de seus deveres, praticam o mal sem motivos especiais, de maneira gratuita, sendo tão pouco capazes de conceber ressentimentos quanto de refletir sobre seus feitos. É essa indiferença à prática do mal que o banaliza. Isso significa que o mal não está no plano da abstração e sim "num nível estritamente factual que nos encarou de frente no julgamento" (ARENDT, 2013, p. 310). Ela o vê como um homem "assustadoramente normal" e foi essa aparente normalidade de Eichmann que lhe causou espanto, ao mesmo tempo que a motivou na tentativa de compreendê-lo sem demonizá-lo. Tratá-lo como um demônio teria sido simplista ou até "reconfortante" afirmou ela (ARENDT, 2013, p. 299). Seu interesse era compreender a figura de Eichmann a fundo - "agiu como filósofa" peculiar o perfil e o modo de pensar do sujeito, bem como as motivações de um ex-nazista como ele.

Embora a autora tenha construído um modelo diferenciado para explicar o fenômeno Eichmann, inclusive ao qualificar o mal como sendo banal, sofreu feroz oposição a algumas de suas ideias, principalmente quando referiu-se a uma possível participação de judeus no massacre de seu próprio povo. Segundo Correia, o que "incomodou em sua análise, entre outros aspectos, foi justamente o fato de ela ter concebido uma teoria na qual o perpetrador do mal possivelmente não possui qualquer diferença essencial de suas vítimas" (CORREIA, 2007, p. 51). Ao insinuar a cooperação de lideranças judaicas que segundo ela podem ter facilitado o "holocausto ${ }^{5}$ ou shoah". Arendt diz que, "para um

\footnotetext{
${ }^{4}$ Mesmo com formação em Filosofia e tendo lecionado Filosofia, Hannah Arendt não se sentia uma absoluta filósofa, preferia ser vista como pensadora de Teoria Política. Conforme entrevista concedida a Günter Glaus, em 28 de outubro de 1964, para um canal de televisão da Alemanha Ocidental. É possível obter o conteúdo dela por meio de duas fontes: Em uma de suas obras denominada "A dignidade da política", publicada em português pela Editora Relume Dumará, p. 123 a 143. E também disponível no site Youtube, com possíveis legendas em português: <https://www.youtube.com/watch?v=WDovm3A1wl4> Acesso em: 11 mar. 2017.

${ }^{5}$ A palavra "holocausto", de origem grega holókauston e conotação bíblica, significa "sacrifício em que a vítima é queimada viva", ou "sacrifício pelo fogo". Foi usada na tradução grega da Bíblia para a palavra hebraica oleh, que designa um tipo de sacrifício dedicado a Deus, portanto apresenta o mesmo significado entre os antigos hebreus. Pela sua significação, a palavra holocausto é considerada inapropriada, mas ela adquiriu na historiografia e na literatura o sentido histórico que expressa o termo "shoah", atualmente mais utilizado. Shoah representa literalmente: ruína, destruição, catástrofe e define o fenômeno de destruição sistemática e socioeconômica, perseguição, expropriação, trabalho forçado, vivência em guetos, tortura e o extermínio de aproximadamente seis milhões de judeus pela política eliminacionista do Partido Nacional Socialista dos Trabalhadores Alemães ou Partido Nazista de Adolf Hitler.Diversitas-
} 
judeu, o papel desempenhado pelos seus líderes judeus na destruição de seu próprio povo é, sem nenhuma dúvida, o capítulo mais sombrio de toda uma história de sombras". (ARENDT, 2013, p. 134).

Percebe-se que, para a autora, esse era um novo tipo de fenômeno em seu tempo e tinha que ser compreendido, pois se tratava de um criminoso acusado de conduzir milhões de judeus à morte, sem que suas práticas fossem movidas por requintes de crueldade ou motivos especiais. Eram práticas cruéis que se tornaram banais e podem ser praticadas por qualquer pessoa caso uma ordem seja dada - o que é muito grave, porque pode se proliferar rapidamente contra qualquer grupo inclusive na atualidade.

Os crimes de Eichmann "inegavelmente ocorreram dentro de uma ordem legal. Essa era, de fato, a sua característica mais notável" (ARENDT, 2013, p. 314). Pois, conduziu milhões de seres humanos à morte dentro da legalidade em um Estado de direito e soberano. Ele cumpria o seu dever, como repetiu insistentemente à polícia e à corte; ele não só obedecia ordens, ele também obedecia à lei" (ARENDT, 2013, p. 152). Eichmann era de fato um homem que cumpriu ordens baseadas em todas as leis de seu país, em uma estrutura de "automatismo burocrático amoral" (GRESPAN, 2013, p. 167). Diante das leis de seu Estado que possuía o perfil de uma "humanidade desamparada de valores", onde suas ações de fato não eram criminosas (FERRAZ, 1983, p. 09). Daí o problema jurídico proveniente desse tipo de Estado segundo Arendt, pois "crimes desse tipo só podem ser cometidos por uma lei criminosa e num Estado criminoso" (ARENDT, 2013, p. 284). A responsabilidade individual acaba sendo diluída pelo sistema e introjeta no indivíduo a sensação de dever cumprido, portanto, sem responsabilidade pessoal alguma pelos feitos porque tudo emana do sistema e está previsto no regulamento, como cita Arendt:

\footnotetext{
Em todo sistema burocrático, a transferência de responsabilidades é uma questão de rotina diária, e se desejamos definir a burocracia [...] é como uma forma de governo - o mando dos cargos, em oposição ao mando de homens, de um único homem, de poucos ou de muitos -, a burocracia é infelizmente o mando de ninguém e, por essa mesma razão, talvez a forma menos humana e mais cruel de governo (ARENDT, 2004, p. 94).
} 
Segundo lição de Correa, "para um burocrata como foi Eichmann, a função que Ihe é própria não é da sua responsabilidade, mas sim a de executar" (CORREIA, 2004, p. 93). Neste caso e na perspectiva de Arendt, a figura do burocrata é vista como um agente da banalidade do mal que realizava massacres administrativos sempre nos limites das leis de seu país e por isso não se sentia responsável. Eichmann operava a burocracia tecnicamente de forma a não permitir que os sentimentos e emoções pessoais conflitassem ou interferissem em suas ideias e nas ordens que obedecia ao longo de seu exercício profissional.

O fato de Arendt afirmar que Eichmann nunca compreendeu o que estava fazendo se relaciona também com a burocracia. Segundo a autora, "a burocracia tinha a intenção de excluir toda a iniciativa individual quer para melhorar a situação, quer para piorá-la. Portanto, o extermínio de milhões foi planejado para funcionar como uma máquina" (ARENDT, 2004, p. 319). O fato de Eichmann atuar em uma escrivaninha assinando papéis e acatando ordens, era como se não desse a ele a sensação de culpa ou clareza moral da natureza criminosa de seus atos. Mesmo assim, é possível consider-a-lo como sendo um dos maiores criminosos de seu tempo, pois estava amparado pelas leis de seu Estado que "transformou o crime em virtude, a violência em valor positivo e - mais do que isso - o crime tornou-se legal e passou a ser um dever" (GUTERMAN, 2013, p. 30).

Portanto, o indivíduo que não almeja ser considerado um criminoso, mas ao mesmo tempo tem de fazê-lo "porque cumpre ordens em um sistema que exige obediência, então que se recuse a apoiar ditaduras e não assuma responsabilidades e compromissos em apoio a uma ditadura" (ARENDT, 2004, p. 110). Daí por que ela rejeitou as alegações da defesa em torno da ideia de que Eichmann era somente um dente de uma grande engrenagem, que recebia ordens com dever de cumpri-las.

A corte de Jerusalém também entendeu que ele deveria ser responsabilizado, isto quer dizer que a alegação da defesa de que os crimes deveriam ser considerados como "atos de Estado" foi recusada e a responsabilidade foi atribuída ao sujeito Eichmann e não ao seu Estado. Após a declaração da sentença a defesa pediu clemência, o que Ihe foi negado. Tentou articular a deportação do réu para a Alemanha, o que não foi possível, pois não havia mais tempo. Em menos de duas horas, Eichmann foi encaminhado à forca na 
prisão de Ramleh, em 31 de maio de 1962 e sem tempo para uma última refeição. Seu corpo foi cremado e as cinzas jogadas no Mediterrâneo, mas não em águas israelenses. Embora a pena de morte exista formalmente na legislação de Israel desde 1945, este foi o único caso em que ela foi aplicada até o momento por este Estado, sendo que naquele período discutia-se a possibilidade de extingui-la, e isso não ocorreu.

Por fim, embora Arendt tenha feito duras críticas ao julgamento, ela se mostrou satisfeita com a sentença e elogiou o trabalho realizado pela corte de Jerusalém, ela a chamou de Casa da Justiça. Os elogios de Arendt à corte - ao afirmar que os juízes tiveram um comportamento honroso, por exemplo - reforçam claramente a perspectiva segundo a qual o julgamento foi muito mais moral do que legal. Com a ressalva que "julgamentos morais" não se enquadram nos parâmetros legais escritos com leis positivadas, portanto, são passíveis de erros e "um terreno escorregadio com alguma esperança de encontrar apoio para os pés" (ARENDT, 2004, p. 89). Mesmo assim, a autora considera justificável - nesse caso - o fato de o julgamento ter sido mais moral do que legal, dado o "horror cometido pelos nazistas que transcendia todas as categorias morais e explodiu todos os padrões de jurisdição conhecidos; era algo que os homens não podiam punir adequadamente, nem perdoar" (ARENDT, 2004, p. 85).

\section{REFERÊNCIAS}

ADLER, Laure. Nos passos de Hannah Arendt. São Paulo: Record, 2007. ARENDT, H. Eichmann em Jerusalém um relato sobre a banalidade do mal. São Paulo: Companhia das Letras, 2013.

ARENDT, H. A dignidade da política. Rio de Janeiro: Relume Dumará, 2003.

ARENDT, H. Origens do totalitarismo. São Paulo: Companhia das Letras, 2009.

ARENDT, H. Responsabilidade e julgamento. São Paulo: Companhia das Letras, 2004.

BAZELAIRE, Jean-Paul; CRETIN, Thierry. A justiça penal internacional. São Paulo: Manole, 2004.

CORREIA, Adriano. Hannah Arendt. Rio de Janeiro: Jorge Zahar Editora, 2007.

CORREIA, Adriano. Crime e responsabilidade: a reflexão de Hannah Arendt sobre o direito e a dominação totalitária. In: DUARTE, André et al. (Org.). A banalização da violência: a atualidade do pensamento de Hannah Arendt. Rio de Janeiro: Relume Dumará, 2004. p. 83-98. 
DUARTE, André. O pensamento a sombra da ruptura: política e filosofia em Hannah Arendt. São Paulo: Paz e Terra, 2000.

FRY, Karin A. Compreender Hannah Arendt. Petrópolis: Vozes, 2010.

GRESPAN, Jorge. Hannah Arendt e a banalidade do mal. In: BADER,Wolfgang; JORGE, Almeida de. (Org.). O pensamento alemão no século XX. Vol. I. São Paulo: Cosac Naify, 2013.

GUTERMAN, Marcos. A moral nazista - uma análise do processo que transformou crime em virtude na Alemanha de Hitler. São Paulo: Tese (doutorado) Universidade de São Paulo - USP, 2013. Disponível em: <file:///C:/Users/Fabiano/Downloads/2013_Marcos Guterman\%20(2).pdf> Acesso em: 08 jan. 2015.

LAFER, Celso. Reflexões sobre a atualidade da análise de Hannah Arendt sobre o Processo Eichmann. In: BREPOHL, Marion (Org.). Curitiba: Editora UFPR, 2013.

LUZ, Marilane Ramos. Arendt e a questão da responsabilidade. Disponível em: <http://www.theoria.com.br/edicao15/arendt_e_a_quest\%C3\%A3o_da_responsabilidade. pdf> Acesso em 10 mai. 2015.

KELSON, Ruth. Hannah Arendt e o âmbito do conceito de banalidade do mal. São Paulo: Dissertação (mestrado) Pontifícia Universidade Católica de São Paulo - PUC SP, 2011. Disponível em: <http://www.sapientia.pucsp.br/tde_arquivos/7/TDE-2011-1123T12:45:15Z-11806/Publico/Ruth\%20Kelson.pdf> Acesso em: 25 jan. 2015.

PEREIRA, Wagner Pinheiro. 0 julgamento de Nuremberg e de Eichmann em Jerusalém: 0 cinema como fonte, prova documental e estratégia pedagógica. Disponível em: <http://www.dhnet.org.br/direitos/anthist/nuremberg/eichmann_nuremberg_israel.p df>. Acesso em: 22 dez. 2014.

SOUKI, Nádia. Hannah Arendt e a banalidade do mal. Belo Horizonte: UFMG, 2006.

TIZZO, Fabiano. Hannah Arendt: política e responsabilidade no julgamento de Eichmann. Dissertação (mestrado). PUC - SP, 2015. Disponível em: <http://www.sapientia.pucsp.br/tde_busca/arquivo.php?codArquivo=18741> Acesso em: 12 mar. 2016.

VOEGELIN, Eric. Hitler e os alemães. São Paulo: Realizações Editora, 2009.

YOUNG-BRUEHL, Elizabeth. Hannah Arendt: una biografía. Barcelona: Paidós, 2006.

TIZZO, Fabiano Miranda do Nascimento. A banalidade do

mal e o julgamento de Eichmann. RBSD - Revista

Brasileira de Sociologia do Direito, v. 4, n. 1, p. 22-37,

jan./abr. 2017. 